\title{
The Effect of Students' Knowledge about Ideology of Translation on Their Translation Qualitative Assessment of a Screen Script
}

\author{
Nasim Mohiman \\ The University of Isfahan, Iran \\ Darjuish Nejadansari \\ The University of Isfahan, Iran
}

\begin{abstract}
This paper aims to compare the Stagecoach screen script, written by Dudley Nichols and Ben Hecht, (1939) with its Persian translation by Vandad Alvandipour (2009), based on three constraints_discoursal constraints, textual constraints and generic constraints_ proposed by Ian Hatim and Basil Mason (1990) as the components of semiotic dimension of a text and as a method of ideological evaluation of translation. After the comparison, a test was designed in a multiple choice format and was given to two groups of M.A translation studies students (21 students in each group) to check their knowledge on ideology in translation studies. The survey was conducted giving one group a treatment (the application of three constraints in a text to give students a viewpoint on how to apply ideological components in a text) before the second test was given to both groups. The second test aimed at evaluating the student's ability in applying their knowledge for assessing the translation of a screen script. The result shows that although students had average level of knowledge about the subject (according to the result of the first test), they were unaware of the applicability of these constraints (according to the result of the second test). These findings encourage the increasing integration of applied courses into the translation curricula, as translation students only enjoy pure theoretical translation courses.
\end{abstract}

Index Terms - screen script, translation, ideology, assessment, discourse

\section{INTRODUCTION}

One of the famous writings of the $20^{\text {th }}$ century is screen script writing. It has been seen many times that screen scripts are delivered to the markets in a novel, story or poem format. However, can screen script be considered as a story or a poem? There are two points of views for screen script evaluation:

a) Screen script is an instrumental writing in which the description of the production process of a movie, scene description, description of the place of objects, along with the dialogues between two or more people are included. This kind of writing has no value by itself and may be put aside after the shooting and editing process and become completely useless.

b) Adopting a literary view point, screen script can be regarded as the beginning of a cinematic innovation and through the literal view point. Sometimes a screen script is not the mere instruction of different processes of shooting, but it has a kind of innovation in its essence which can be considered as a literary work, especially if the writer is famous and has many other literary masterpieces. As an example, Bahram Beyzaei who has many screenplays in the history of theatre in Iran is well-known in the country for his valuable screenscript. There is a literal innovation in his screen scripts especially in his dialogues, scene description and style of narration.

Screen scripts were not like what we can see today. The first scripts of cinema were like a short written description which were brought to the location and the rest of the story was produced spontaneously by the director. After the $20^{\text {th }}$ century the screenwriting expanded and changed to the developed structures with specific rules.

Screenscript translations in Iran started from translation of only summary of scripts. Persons who started this translation in Iran were Parviz Taeedi and Hooshang Taheri.For example Nights of Cabiria (1957) by Federico Fellini was translated by Parviz Taeedi and so did Citizen Kane (1941) in 1978. Hooshang Taheri translated many books from German language to Persian. Some of the screenscripts translated by him are as follow: Hiroshima my love (1959), translated in 1969, Wild strawberry (1957) by Ingmar Bergman, translated in 1969, Red desert (1964) by Michleangelo Antonioni and Nazarin(1959) by Luis Bunuel. Also Gholamhossein Saedi translated Cow in 1973.

Screenscript in comparison with screenplay or novel does not have a literary independency and nobility. Many of them have been printed and delivered to the market based on the literary essence of the screenscripts. The elements of a movie script consists of characters, location, plot, sounds, etc. A script consists of three acts structures; the three acts are setup (of the location and characters), confrontation (with an obstacle), and resolution (culminating in a climax and a dénouement). There are three bodies of a script: Headings- including camera location, time, and scene location etc, 
Narrative-including action, sounds, character and setting, dialogue-including the name of the person, the actor direction and speech.

Screenscript translation involves transferring dialogs, scene descriptions, guidelines for directors, and cameraman into the target language. In translating a screenplay, dialogues are very important and as Reiss (2000) holds films should be translated in a way to "preserve the same effect on the hearer that the original has in the source language." (p.46) The translator of a screenscript should be interested in cinema as well as being expert in translation .The screen script should not be translated like a novel with extreme literally dialogues which makes it hard to understand in a time constraints. Unlike reading a book in which we can go back and read the paragraphs that we did not understand before, watching a movie necessitates instant understanding of the screen script, therefore a screen script should be translated in an easier way. For translating a script, it's not enough to know the terminology of the screen; a translator must also be able to transfer horror, pain, joy or suspense from the original script.

As screenscript translating is a challenging work and the translator should consider different aspects like writing principles, linguistic differences, pragmatics etc., this research first analyzes the translation based on three constraints that B.Hatim and I.Mason proposed for translation evaluation and ideology analysis. As J.Munday mentions in his 'Introducing translation studies': "They pay extra attention to the realization in translation of ideational and interpersonal functions (rather than just the textual function) and incorporate into their model a semiotic level of discourse" (2001, p.97). Basic principles of their model are based on Hallidayan Model of language and discourse which looks at language as communication. Here linguistic choices are important as they are representative of sociocultural framework. There is a difference between House and Hatim \& Mason theory. The main difference is the definition of discourse in these two models. Hatim and Mason define discourse as, "modes of speaking and writing which involves social groups in adopting a particular attitude towards areas of sociocultural activity. (For example Racist discourse, bureaucratese,etc)

(As cited by Munday, p.236)

Fundamentally, Hatim and Mason add the semiotic dimension to their theory which governs the relations between discoursal elements as signs. They propose these three constraints (1994) as parts of semiotic system within which ideology emerges.

Stagecoach (1939) is a classic Western film directed by John Ford. The screenscript, written by Dudley Nichols and Ben Hecht, which is an adaptation of "The Stage to Lordsburg", a 1937 short story by Ernest Haycox . Stagecoach is one of the best samples of the influence of literature on cinema. It performs a main role in the western genre and changed to a classic western prototype. Film theorist André Bazin has written of John Ford's Stagecoach: "Stagecoach is the ideal example of the maturity of a style brought to classic perfection...Stagecoach is like a wheel, so perfectly made that it remains in equilibrium on its axis in any position. (1992, p.366-70)

The plot takes the name of stagecoach as the basis for narrative divisions. This screen script is the story of a group of passengers of a stagecoach each of which is the representative of a sect of a society, they start a journey and at the end all of them will be refined. The main events happen in places where stagecoach stopped for rest and these stops are a change in a routine of a journey with the stagecoach. The destination is future Lordsburg, Lordsburg of justice and social equality. The apaches were representative of wild forces of nature. As critic Andrew Sarris said the big part of stagecoach is Ford's "Double Image; alternating between close-ups of emotional intimacy and long shots of epic involvement, thus capturing both the twitches of life and the silhouettes of legend." Stagecoach changed to the eternal western classic type. The characters become the archetype of western genre; the events made the main dramatic opposition of this genre.

\section{Three Constraints of Semiotic Dimension}

There is a close relationship between translation and social conditions. Translator's act is based on their social conditions while the target and source languages have different societies. Hatim and Mason (1997) also consider translation not as an isolated phenomenon but as a part of social life. They focus on translation process as they believe that if we only focus on the translation product, without considering decision making procedures, our understanding is not comprehensive. They also believe also that it is not possible to have a mere objective model, and they set some parameters for analysis of translation process.

By means of Hatim and Mason's framework we can clarify the linguistic choices expressed in message, the social intention of the originator of the message, unravel the human and conceptual relations which go to make up the context we communicate and uncover the structure and textuality of the text.

In the process of translating a text from one language to another, there are restrictions for exact transferring because of cultural, ideological, social and linguistic differences. Hatim and Mason believe that the translator should transfer the text through linguistic and cultural boundaries; "in doing so, the translator is necessarily handling such matters as intended meaning, implied meaning, presupposed meaning, all on the basis of the evidence of the text." (1997, p.47)

They proposed their framework based on the Hallidayan (1976) model of language. There is a difference between the model of text processing proposed by Hatim and Mason and those proposed by other scholars like Hallidayan and J.House (1977). The difference is that they see text as a social event and therefore the text expressions do not come together accidentally but as motivated by contextual factors. Hatim and Mason believe that social aspect of a text is very important and even more significant than textual genre. They also mention that the social context characterizes 
today's method of translation from those in the past like literal translation, technical translation, and so on. According to them context has three dimensions: communicative, pragmatic and semiotics. They define three constraints within the semiotic dimension of the context; Discoursal constraints, Generic constraints and Textual constraints.

\section{A. Generic Constraints}

Genre (Generic) is conventional forms of texts associated with particular types of social occasion .However; Hatim and Mason hold that there is no matched relationship between lexis and grammar and that the social events are connected with particular genres. Therefore, genre has a significant role in the translator's decision. "The convention of genres are indices of particular cultures which exert a strong influence over the way the genres are to be encoded in a text". (Hatim and Mason 1990, p.70)

As an example of how genre influences the translator's decision look at the following texts:

"a fat man wearing a top hat, places a bottle of whiskey in front of Luke and pulls out the stopper. Looking rather apprehensive, he produces a glass and Luke pours himself a slug of whiskey."

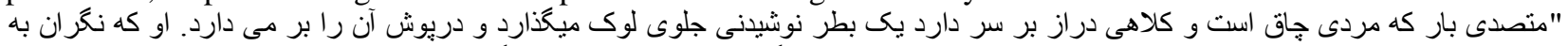

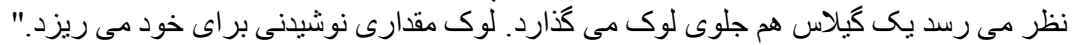

Imotosadi bar ke mardi chagh ast va kolahi deraaz bar sar daard yek botr nooshidani jeloy luke migozarad va dar poosh aan ra bar midarad. Oo ke negaran be nazar miresad yek gilas ham jeloy luke migozarad. Luke meghdari nooshidani baray khod mirizad.I

From the perspective of top-down analysis these two texts have the same generic specification, as both are published as a screen script for readers. Yet, the existence of this genre in two different societies, cultures and religions, causes some differences. Here the word "whiskey" is translated to "drink" which is more general and can include alcoholic and non-alcoholic drinks. The cinematic genre in Iran has some rules and restrictions; the translator cannot use the brand name of alcoholic drinks. This is for religious and social reasons and it may not be acceptable or understandable. However, the cinematic genre in the source conventions does not face such restrictions. Although this is because of social and cultural differences, possibilities exist at the level of lexical selection like other part of the sentence (/Bar/and /Gilas/) to show that this is a kind of alcoholic drink and the translator reduces heterogeneity of the source text and target text. Therefore, this allows target readers to have access to the writer's intention.

\section{B. Discoursal Constraints}

Hatim and Mason believe that the denotational aspect of a word is not enough and that a connotative dimension should be added as well. They also put three categories under the discoursal constraints, they include are coherence, theme and rheme and transitivity.

1. Coherence

Textual occurrences, which are related to grammatical system of language, are contextually motivated. As Hatim and Mason argue "coherence is not something created by text ,but rather an assumption made by language users that ,in accordance with the cooperative principle ,texts are intended to be coherent". (1997, p.194) They defined coherence as conceptual connectivity which include, 1. Logical association, 2. Arrangement of events and 3. Continuity as human experience. The coherence of the text needs to be transferred in translation process. In the following part there are some examples to show the lexical cohesion between English and Persian:

Example 1.

Title: "Until the Iron Horse came, the Stagecoach was the only means of travel on the untamed American frontier. Braving all dangers, these Concord coaches -- the "streamliners" of their day -- spanned on schedule wild, desolate stretches of desert and mountainland in the Southwest, where in 1875 the savage struggle of the Indians to oust the white invader was drawing to a close. At the time no name struck more terror into the hearts of travellers than that of GERONIMO -- leader of those Apaches who preferred death rather than submit to the white man's will."

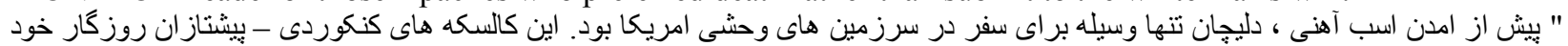

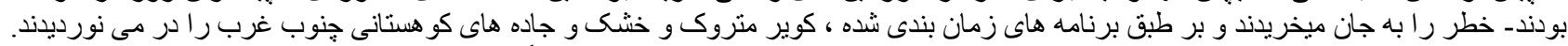

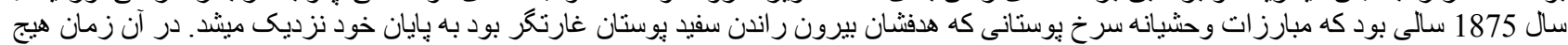

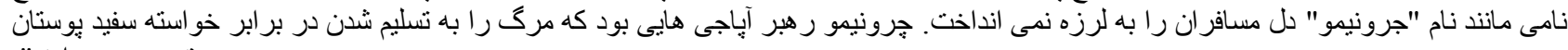
ترجيح مى دادند".

/pish az amadan asb ahani, delijan tanha vasileh baray safar dar sarzamin hay vahshi amrica bood. In kaleskeh haay konkordi_ pishtazan roozgar khod boodand- khatar ra be jaan mikharidand va bar tebgh barnameh hay zamaan bandi shode, kavir matrook va khoshk va jadeh hay koohestaani jonoob gharb ra dar minavardidand. Sal 1875 Sali bood ke mobarezaat vahshianeh sorkh poostaani ke hadfshaan biroon randan sefid poostan gharatgar bood be payan khod nazdik mishod. Dar an zaman hich naami manand nam "Geronimo" del mosaferan ra be larzeh nemi andakht. Geronimo rahbar apache haei bood ke marg ra be taslim shodan dar barabar khasteh hay sefid poostan tarjih midadand. / 
TABLE 1.

THE COMPARISON OF LEXICAL COHESION OF ENGLISH AND PERSIAN TEXT

\begin{tabular}{ll}
\hline English Lexical Cohesion Example for Text 1 & Persian Lexical Cohesion Example for Text 1 \\
\hline Luke Plummer, Luke Plummer, Luke, Luke, he, he, Luke Plummer & Look plammer, Look plammer, Look, Look, Look plammer/ \\
\hline Kid, Kid, Kid, Ringo, him, he, & /Ringo kid, Ringo, Ringo, kid,oon, oon/ \\
\hline First place, Second place, but, and , then, and & \\
\hline Kill, gun-fight, get shot, kill, the pen, fight & /doel, mikoshe, koshte shod, nakoshe,zendoone, zendoon,zendoone/ \\
\hline Kill, kill & \\
\hline Plummer, Plummer, Plummer, Plummer, Plummer & /plammer, plammer, plammer, plammer, plammer/ \\
\hline
\end{tabular}

In order to cover the different aspects of the screen script, another part has been selected from the dialogue between Buck and Curly to investigate the coherence rendered by the translator:

Example 2.

"BUCK

Luke Plummer and the Kid.

(curly merely looks straight ahead)

They'd be a lot more peace on the frontier if Luke Plummer was too full o' lead to hold his liquor.

CURLY

I ain't sayin' I don't share your sentiments, Buck, but you're a born fool. First place Luke would kill the Kid in a gun-fight. Second place if Luke did get shot he's got two brothers jest as ornery as he is, and if Ike Plummer didn't kill the Kid then Hank Plummer would. (he spits off disgustedly)

Nope, safest place for Ringo is in the pen and I aim to get him there all in one piece. Time he gets out Luke Plummer will of picked a fight with the wrong man and it'll all blow over.

BUCK

(looking at Curly with astonishment)

Well, I'll be doggoned! I done you an injury, Curly. I thought you was after the reward.

CURLY

(reproachfully)

Reward! Why, the Kid's old man and me was friends.

(he stares off into the horizon)

Besides, I can use that five hundred in gold."

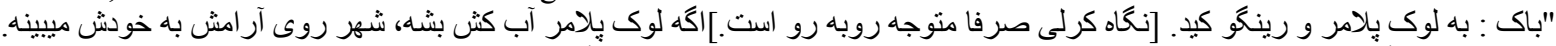

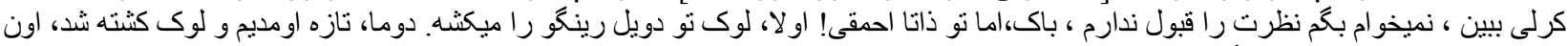

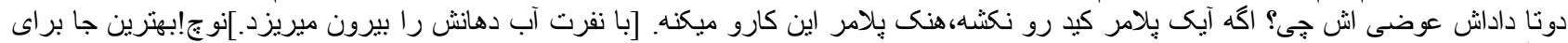

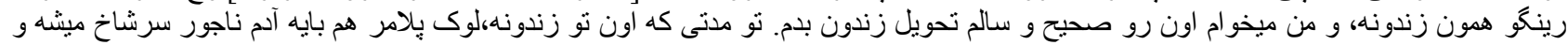

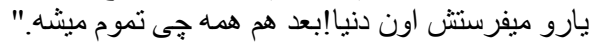

/bak: be luke plummer va ringo kid. [negah kerli serfan motovajeh ro be ro ast.] age luke plummer ab kesh beshe, shahr rooy aramesh be khodesh mibineh./

/kerli bebein, nemikham begam nazart ra ghabool nadaram, buck, ama to zatan ahmaghi! Avalan, luke too doel ringo ra mikoshe. Dovoman, tazeh oomadim va luke koshteh shod, oon dota dadash avazi ash chi? Ageh ayk Plummer kid ro nakoshe, hank Plummer in karo mikone. [ba nefrat ab dahanash ra biroon mirizad] noch! Behtarin ja baray ringo hamoon zendoone, va man mikham oon ro sahih va salm tahvil zendoon bedam. Too modati ke oon too zendoone, luke plummer ham ba ye adam najoor sar shakh mishe va yaro mifrestatsh oon donya! Bad ham hame chi tamoom mishe./

TABLE2.

THE COMPARISON OF LEXICAL COHESION IN ENGLISH AND PERSIAN TEXT

\begin{tabular}{ll}
\hline English Lexical Cohesion for Text 2 & Persian Lexical Cohesion for Text 2 \\
\hline Stagecoach, these, concord coaches, means, streamliners, their & /delijan, vasileh,kaleskeh hay konkordi, in -pishtazan roozgar/ \\
\hline $\begin{array}{l}\text { No name struck more terror } \\
\text { into the hearts of travellers than that of GERONIMO } \\
\text { cohesion) }\end{array}$ & $\begin{array}{l}\text { /Nam, Nami/ } \\
\text { /hich name mannad nam "Geronimo"/ }\end{array}$ \\
\hline $\begin{array}{l}\text { leader, Geronimo, } \\
\text { Indians, those Apaches }\end{array}$ & /Geronimo, Geronimo, rahbar/ \\
\hline the white invader, the white & /sorkh poostani, apache haei/ Sefid poostan gharatgar, sefid poostan/ \\
\hline $\begin{array}{l}\text { the untamed American frontier, desolate stretches of } \\
\text { desert and mountain }\end{array}$ & /kavir matrook va khoshk va jadeh hay koohestani, sarzamin hay vahshi/ \\
\hline was, was & $\begin{array}{l}\text { /Boodand, bood, bood/ } \\
\text { /Sali, sal/ }\end{array}$ \\
\hline
\end{tabular}

This part has been selected from the beginning of the screen script and is related to the narration. Below there are the lexical cohesion found in this specific part: 


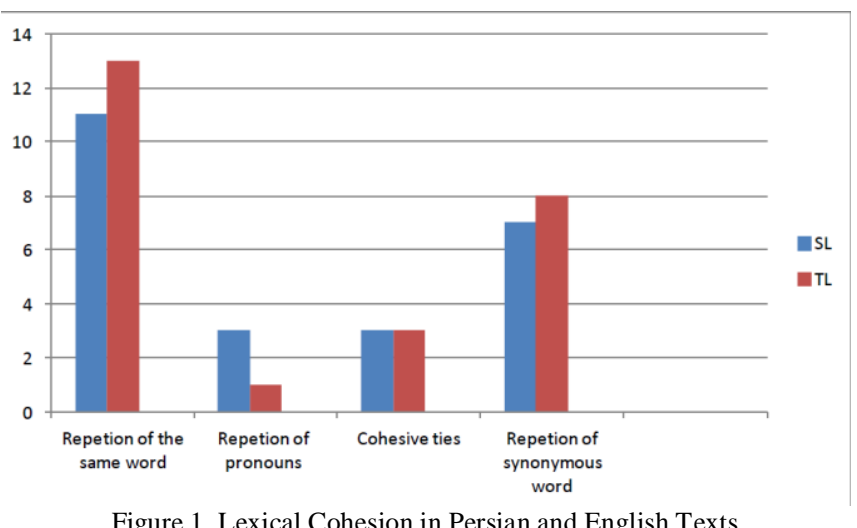

As the chart shows, lexical cohesion can be considered in different ways; through the repetition of the same word, using pronouns, cohesive ties and repetition of synonymous words. The translator repeats the same or synonymous words more than the writer as this can be a compensation for the other issue, i.e., using pronouns. Cohesive ties have been translated properly to the target language.

As Hatim and Mason argue repetition of the words is motivated. Therefore, the translation needs to be relayed. The repetition compromise the overall effect of the text.

2. Theme-Rheme arrangement

One of the aspects of texture is theme-rheme arrangement. Theme and rheme assumption refer to discourse and is not just the property of sentence. "Thematic elements are 'context-dependent' and consequently of lesser communicative importance than 'context-independent' rhematic elements". (Hatim and Mason, 1990, p.212) Theme and rheme ordering is not just a basic word order and is not random which means that it can show aspects of context such as intentionality and text type focus. Theme and rheme ordering involves three aspects: predictability and recoverability, saliency and shared assumption. Translators have to take into account the thematic structure of the original text to preserve the implication and intention of the text producers.

"At the time no name struck more terror into the hearts of travelers than that of GERONIMO"

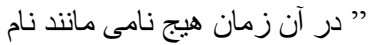

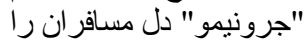

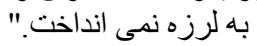

/Dar an zaman hich naami manand naam "Geronimo" del mosaferaan ra be larze nemiandakht./

In English sentence the name of "Geronimo" situated at the end of the sentence which causes more suspense than the Persian translation. In English the reader wants to know the name of the person who "struck more terror into the heart of travelers" but the translation of this sentence come after the name of Geronimo.

"Braving all dangers, these Concord coaches - the "streamliners" of their day -“"

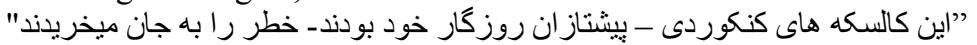

/in kaleskeh hay konkordi- pishtazan roozgar khod boodand- khatar ra be jan mikharidand. /

In this sentence "braving all dangers" is at the beginning of the sentence while in Persian translation it comes at the end of the sentence. Also the place of "Concord coaches" and "streamliners of their day" are changed in Persian translation which change the place of emphasis.

"They'd be a lot more peace on the frontier if Luke Plummer was too full o' lead to hold his liquor."

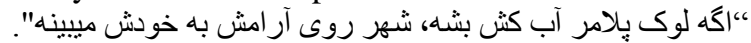

/age luke plummer ab kesh beshe, shahr rooy aramesh be khodesh mibine./

In this sentence the place of rheme and theme is changed. "They'd be a lot more peace on the frontier" comes at the end of the Persian translation.

3. Transitivity

Transitivity refers to the sentence arrangement. Whereas some languages tend to place inanimate actors in theme position, other languages tend to place action.

Example:

"They'd be a lot more peace on the

"شهر روى آر امش به خودش ميبينه

Frontier"

/shahr rooy aramesh be khodesh mibine/

In the English version there is no action but in the Persian translation the verb has object and the sentence metaphorically means "the city can see the peace on it".

"(Curly merely looks straight ahead)"

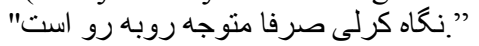

/negah kerli motovajeh ro be rost/ 
Here in English sentence the verb "look" show the action of the sentence in which Curly is the agent. In Persian translation, the look of Curly ("نحاه كرلى") is the subject. The back translation of this sentence is the look of Curly is connected ahead.

"it'll all blow over"

" بارو ميفرسنش اون دنيا "

/yaro mifresatsh oon donya/

In English sentence "it" is subject while in Persian translation there is an agent. The back translation of Persian sentence is 'someone will send him to the other world'. Here there is more action in the sentence while the English sentence means 'it will be finished'.

\section{Textual Constraints}

Hatim and Mason (1991) believe that discourse and genre are too expanded to be able to come to a structured mode of expression. Therefore a more stable framework is needed which will be reached at by adding "text"." Within the model of discourse processing advocated here, a textual structure is one in which communicative intentions are made mutually relevant in the service of a given rhetorical purpose" (Hatim and Mason, 1976, p.90). They considered cohesion as the aspect of texture which by joining sentences together sustains textuality as a coherent text. The meaning behind the cohesion and coherence is when contextual values (including most prominently, text type focus) are reestablished.

For textual analysis Fairclough's framework (1995) is also added to Hatim and Mason's to complete the analysis and also because their explanation is very general and it is difficult to apply it as a framework. Fairclough defines different issues regarding discourse and text analysis, he defines the textual part as a factor connecting parts of text together and connecting texts to their contexts. Fairclough's textual analysis is as follow

Grammatical relations:

a. Patataxis: Equal or coordinate clauses: The birds were singing and the fish were jumping.

b. Hypotaxis: Subordinate a clause to the main clause: The birds were singing because the sun was shining.

c. Embedding: One clause functions as an element of another clause (its subject) or as an element of a opharse: The man who came to dinner...

Semantic relations:

A. Causal

A1. Reason (because...)

A.2. Consequence (so...)

A3.Purpose (in order to...)

B. Conditional (if)

C. Temporal (when)

D. Additive (And)

E. Elaboration (Exemplification or rewording)

F. Contrastive/Concessive (but)

Example 3.

Text 1

"He takes one last look at her, then digs his spurs into the mustang and the horse leaps forward. Camera pans left slightly as he canters off, leaving Dallas watching him ride away, her arm lifted in a little gesture of farewell.

Pan left with Ringo as he rides his horse hard, jumping the fence that rings the compound and galloping to the top of a rise a hundred feet away. As he tops the rise, galloping straight forward, he suddenly sees something that makes him saw on the bit. The horse comes to a dead stop as if it had four-wheel brakes. He dismounts again, looking around.

Dallas is watching anxiously from outside the corral. Her arm is still half-up in her incomplete gesture. From behind her comes Curly's voice."

Persian Translation:

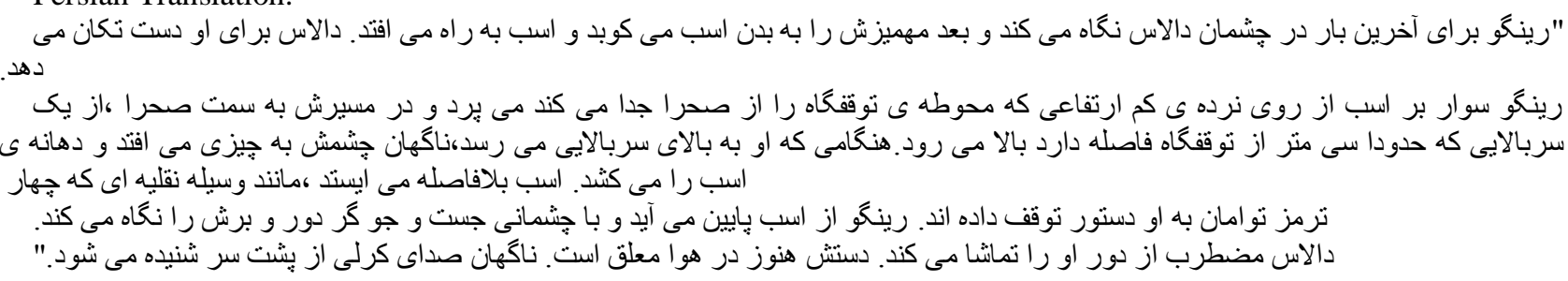

/Ringo baray akharin bar dar cheshman dalas negah mikonad va bad mehmizash ra be badan asb mikobad va asb be rah mioftad. Dalas baray oo dast tekan midahad./

/ringo savar bar asb az rooy nardeh y kam ertefaee ke mohavateh y tavaghofgah ra az sahra joda mikonad miparad va dar masirash be samt sahra, az yek sar balaei ke hododan si metr az tavaghofgah faseleh darad bala miravad, hengami ke oo be balay sar balaei miresad, nagahan cheshmash be chizi mioftad va dahaneh asb ra mikeshad. Asb belafaseleh mi isad, mannad vasileh naghlieh ke chahar tormoz toaman be oo dastoor tavaghof dadeh and. Ringi az asb paeen miayad va ba cheshmani joso joo gar dor o barash ra negah mikonad./ 
/dalas moztarb az door oo ra tamasha mikonad. Dastash hanooz dar hava moalgh ast. Nagahan seday kerli az posht shenideh mishavad/

Gramatical Relation Example (1)

TABLE 3.

COMPARISON OF GRAMMATICAL RELATION IN ENGLISH AND PERSIAN TEXT

\begin{tabular}{|c|c|}
\hline Gramatical Relations for English Text & Gramatical Relation for Persian Text \\
\hline $\begin{array}{l}\text { "Pan left with Ringo as he rides his horse hard, jumping the fence that } \\
\text { rings the compound and galloping to the top of a rise a hundred feet } \\
\text { away." }\end{array}$ & $\begin{array}{l}\text { Patataxis : } \\
\text { /ringo savar bar asb az rooy nardeh y kam ertefaaei ke mohavateh y } \\
\text { tavaghofgah ra az sahra joda mikonad miparad va da masirash be samt } \\
\text { sahra, az yek sar balaei ke hodoodan si metr az tavaghofgah faseleh } \\
\text { darad bala miravad./ } \\
\text { /nagahan cheshmash be chizi mioftad va dahaneh y asb ra mikeshad/ } \\
\text { /ringo az asb paein miayad va ba cheshmani jost o joo gar dor o barash ra } \\
\text { negah mikonad/ }\end{array}$ \\
\hline $\begin{array}{l}\text { Hypotaxis: } \\
\text { "Pan left with Ringo as he rides his horse hard, jumping the } \\
\text { fence that rings the compound and galloping to the top" } \\
\text { "Camera pans left slightly as he canters off leaving Dallas watching him } \\
\text { ride away, her arm lifted in a little gesture of farewell." } \\
\text { "As he tops the rise, galloping straight forward, he suddenly sees } \\
\text { something that makes him saw on the bit." }\end{array}$ & $\begin{array}{l}\text { Embedding : } \\
\text { / ringo savar bar asb az rooy nardeh y kam ertefaaei ke mohavateh y } \\
\text { tavaghofgah ra az sahra joda mikonad miparad/ } \\
\text { laz yek sar balaei ke hodoodan si metr az tavaghofgah faseleh darad bala } \\
\text { miravad./ }\end{array}$ \\
\hline $\begin{array}{l}\text { Embedding: } \\
\text { " he suddenly sees something that makes him saw on the bit" } \\
\text { " jumping the fence that rings the compound" }\end{array}$ & \\
\hline
\end{tabular}

Example 4.

"MRS. PICKETT

There ain't no soldiers here but what you see.

LUCY

(anxiously)

But my husband, Captain Mallory. I was told he was here.

\section{MRS. PICKETT}

(off)

He was, dearie. Got orders night afore last to join the soldiers at Apache Wells.

Lucy, very upset, turns away, trying to be courageous, but the strain shows.

BUCK

(off)

Well, that means we got to turn back.

\section{GATEWOOD}

(off)

I can't go back.

(he catches hold of himself and blusters)

See here, driver, this stage has started for Lordsburg and it's your duty to get us there."

Persian Translation:

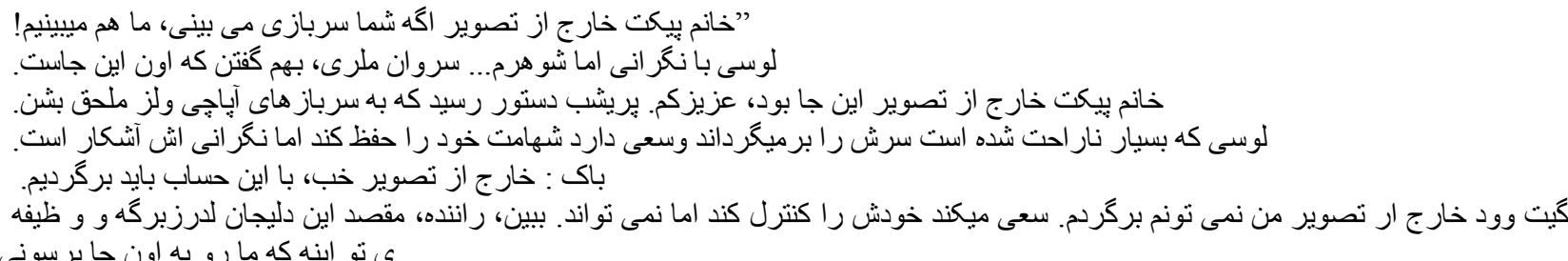

/khanoom piket kharj az tasvir ageh shoma sarbazi mibini, ma ham mibinim/

/loosi ba negarani ama shoharam...sarvan merli, beham goftan ke oon injast./

/khanoom picket kharj az tasvir in ja bod, azizakam. Parishab dastoor resid ke be sarbaz hay apache velz molhagh beshan/

/loosi ke besiar narahat shod east sarash ra bar migardanad va say darad shahamat khod ra hefz konad ama negarani ash ashkar ast./

Buck: kharej az tasvir khob ba in hesab bayad bargardim.

Gatewood kharj az tasvir man nemitoonam bargardam. Say mikonad khodash ra control konad ama nemitavanad.

Bebin, rananadeh, maghsad in delijan lodersborg e va vazifeh y to in eke ma ro be oonja beresooni./

Semantic Relations: 
TABLE 4.

COMPARISON OF PERSIAN AND ENGLISH SEMANTIC RELATION

\begin{tabular}{|c|c|}
\hline Semantic Relation in English Text & Semantic Relation in Persian Text \\
\hline $\begin{array}{l}\text { Purpose : "Got orders night afore last to join the soldiers at Apache } \\
\text { Wells." }\end{array}$ & $\begin{array}{l}\text { Conditional : } \\
\text { /age shoma sarbazi mibini, ma ham mibinim!/ }\end{array}$ \\
\hline $\begin{array}{l}\text { Additive : } \\
\text { " he catches hold of himself and blusters" . } \\
\text { ". this stage has started for Lordsburg and it's your duty to get us there." }\end{array}$ & $\begin{array}{l}\text { Contrastive : } \\
\text { /va say darad shahamat khod ra hefz konad ama negarani ash ashkar } \\
\text { ast/ } \\
\text { /loosi ba negarani ama shoharam/ }\end{array}$ \\
\hline $\begin{array}{l}\text { Elaboration : } \\
\text {."Well, that means we got to turn back." }\end{array}$ & $\begin{array}{l}\text { Additive : } \\
\text { /maghsad in delijan lodrzborge va vazife y to in eke ma ro be oon ja } \\
\text { beresooni/ } \\
\text { loosi ke besiar narahat shod east sarash ra bar migardanad va say } \\
\text { darad shahamat khod ra hefz konad/ }\end{array}$ \\
\hline \multicolumn{2}{|l|}{$\begin{array}{l}\text { Contrastive : } \\
. " \text { There ain't no soldiers here but what you see". } \\
. " \text { But my husband, Captain Mallory" } \\
. \text { " trying to be courageous, but the strain shows". }\end{array}$} \\
\hline $\begin{array}{l}\text { Hypotaxis : } \\
\text { "Lucy, very upset, turns away, trying to be courageous" }\end{array}$ & \\
\hline
\end{tabular}

The comparison shows that semantic relations are not equal in English and Persian sentences. As it is mentioned above, the subcategories of semantic relation exist in both Persian and English sentences but they do not occur at the same place.

\section{Survey on knowledge of students and their ability in applying it}

For the second part of this paper, two separate groups of M.A translation studies students from the University of Isfahan were chosen. There were twenty one members in each class. One group was the control group and the other one, the experimental group. At first, , a pre test was given to each group to see the degree of their knowledge about the ideology of translation, which included 25 questions regarding different aspect of ideology, discoursal, textual, generic factors for translation evaluation in general as well as questions about Hatim and Mason \& Fairclough's framework. After the pretest, a paper was given to the experimental group which included the example of application of three constraints (the combination of Hatim and Mason and Fairclough's framework) in a text to clarify the application of such theory. After that, another test with 25 sentences, in which there were some parts of Stagecoach screenscrip with its Persian translation, was given to the students to evaluate the ideology of translation according to the discoursal, textual and generic factors or any other factors they have in their mind. Participants of the control group were not forewarned in any way before the second test, no explanation was given after the pretest and immediately they replied to the second test.

\section{RESULTS}

The result of this paper is based on the differences between the control and the experimental group. The result of the pre test shows that both classes have a similar level of knowledge on the subject matter. As this is shown in Table 1, the means of two groups are very close, i.e., the mean of control group is 13. 62 and that of experimental is 13.14. The results of $\mathrm{T}$ test shows that there are no significant differences between the means of two groups.

TABLE 5.

PAIRED SAMPLES T TEST

\begin{tabular}{lllllc}
\hline \multicolumn{5}{c}{} & \multicolumn{5}{c}{ PAIRED SAMPLES T TEST } \\
\hline \multirow{2}{*}{ Pair 1 } & Mean & $\mathrm{N}$ & Std. Deviation & Std. Error Mean \\
& control & 13.62 & 21 & 1.962 & .428 \\
& experimental & 13.14 & 21 & 2.57460 & .56182 \\
\hline
\end{tabular}

Furthermore, as Table 2 shows, the mean of posttest of the experimental group, after receiving the treatment, is more than the control group which signifies the effect of the treatment on the experimental group. This shows that the mean of the control group for post test was 12.14 and for the experimental group was 20.76. The result of paired sample T test reveals that there is a significant difference between the means of the two groups. The findings illustrate that although both classes had similar degree of knowledge about the subject, the experimental group was more successful in applying this knowledge in the evaluation of translation because they got familiar with the tangible instances of application of their knowledge in analyzing a screen text along with its translation.

TABLE 6.

PAIRED SAMPLES T TEST

\begin{tabular}{llllll}
\hline & & Mean & N & Std. Deviation & Std. Error Mean \\
\hline Pair 1 & postcontrol & 12.14 & 21 & 2.104 & .459 \\
& postexprimental & 20.76 & 21 & 2.68151 & .58515 \\
\hline
\end{tabular}




\section{CONCLUSION}

This study can provide several implications to translation studies students. The first implication of this study is for translation student that just studying translation theories is not enough for translated text evaluation. They need to know how to apply these theories in a text as well. Secondly, translation teachers and syllabus designers can benefit from the results of this study. Just including theoretical courses does not seem to be effective for translation students. They should also get familiar with applications and actual analysis of translated texts in order to get improved in their courses. Moreover, materials developers can get great hints from the present study in providing effective textbooks for translation studies students. This study focused on the three constraints of ideology evaluation (Discoursal, Textual and Generic) in translation, proposed by Hatim and Mason and also a framework of textuality by Fairclough. John Ford's Stagecoach screenscript was chosen as the basis of the study. In the first part of the paper, Hatim and Mason and Fairclugh's frameworks were applied in some part of this screen script, both in Persian and English version to evaluate the target text based on these two frameworks. In the second part of the paper, a survey has been done on two groups of translation studies student. Group A replied to a pretest and a posttest and group B replied to the same pretest, received a treatment and replied to the same post-test. The result showed that the experimental group significantly outperformed the control group in evaluating a text and its translation.

\section{REFERENCES}

[1] Baines, Lawrence. May. (1996). From Page to Screen: When a Novel Is Interpreted for Film, What Gets Lost in the Translation? Journal of Adolescent \& Adult Literacy, Vol. 39, No. 8. 612- 622

[2] Bassnett, Susan. (1978). Translating Spatial Poetry: An Examination of Theatre Texts in Performance. Literature and Translation. Eds. J. S. Holmes, et al. Leuven: ACCO. 161-76.

[3] Bordwell, D, Thompson, K.(1992). FilmArt. $4^{\text {th }}$ edition. New York: McGraw-Hill publication

[4] Coen, Ethon; Coen, Joel. (2002). Ethon Coen and Joel Coen Collected Screenplays. . London: Faber and Faber.

[5] Cook, David A. (1990). By Hooshang azarivar Trans. Tarikh Cinemay Jahan (A History of Narrative Film) 2nd edition. Tehran: Cheshme,

[6] Cook, David. A. (2001). By Hoshang Azadivar Trans. Tarikh Cinemay Jahan (A History of Narrative Film), Tehran: Cheshmeh.

[7] Cronenberg, David. (2006). Interviews by Serge Grunberg. New Jersey: Plexus Publishing.

[8] Delabastita, Dirk. (1990). Translation and the mass media". In Susan Bassnett and André Lefevere (eds) Translation, History and Culture. London: Pinter Publishers.

[9] Fairclough, Norman. (2003). Analyzing Discourse: Textual Analysis for Social Research. New York: Routledge.

[10] Fairclough, Norman. (1995). Critical Discourse Analysis: The Critical Study of Language. London and New York: Longman.

[11] Fairclough, Norman. (1992). Discourse and Social Change. UK: Polity Press.

[12] Ghazanfari, Mohammad. (2004). Negahi bar Chaharchhob Tahlili Baztaab Jahanbini Dar Tarjome va Mesdagh hay an dar Tarjome hay Adabi (looking on Analatical Framework of Ideology in Translation and its Tokens in Literary Translation). Research and studies of literature and Humanities Journal 2.42,185- 203

[13] Golden, John. Sep. (2007). Literature into Film (and Back Again): Another Look at an Old DogAuthor(s). The English Journal, Vol. 97, No. 1. 24-30. National Council of Teachers of English

[14] Halliday, Michael Alexander Kirkwood. and Hasan, Ruqaiya .(1976). Cohesion in English. London and New York: Longman.

[15] Hatim,Basil,Mason, Ian. (1991). Coping with Ideology in Professional Translating. Interface: Journal of Applied Linguistics, $6(1), 23-32$

[16] Hatim,Basil; Mason, Ian. (1990). Discourse and the translator. London and New York: Longman.

[17] Hatim, Basil; Mason, Ian. (1997). The Translator as Communicator. London and New York: Routledge.

[18] Hatim,Basil ;Munday, Jeremy. (2004). Translation an Advanced Resource Book. New York: Routledge

[19] Jamali , Omid, (1998). Tarikh Sinamay Iran . (History of Iranian Movies), Vol 1 .Tehran: Rozaneh.

[20] Jamali, Omid, (2004).Tarikh Sinamay Iran (History of Iranian Movies), Vol 2. Tehran: Rozaneh.

[21] Munday, Jeremy. (2001). Introducing Translation Studies. Theories and Applications. London and New York: Routledge.

[22] Nichols, Dudley. (2009). Delijan. (Stagecoach). Trans. Alvadipour, Vandad. Tehran: Ney.

[23] Nichols, Dudley. (1939). Stagecoach (based on the short story, Stage to Lordsburg by Ernest Haycox and Ben Hecht) Script City: Hollywood

[24] Reiss, K. (2000). Translation Criticism - The Potentials \& Limitations, Manchester: St. Jerome Publishing.

[25] Schary, Dore. Mar.(1954). Literature and the Screen. The English Journal, Vol. 43, No. 3. 135-141. Published by: National Council of Teachers of English

[26] Wikipedia: The free encyclopedia. FL: Wikimedia Foundation, Inc. (2004). http://www.wikipedia.org (accessed 20/8/2011)

[27] Zhang, Chunbai. (2004). The Translating of Screenplays in the Mainland of China. Volume 49, numéro 1, avril, p. $182-192$ Meta

Nasim Mohiman teaches Translation studies at the Iranian Center for Education, Culture and Research (Isfahan University of Technology). Her areas of research include discourse analysis, contrastive analysis and translation criticism. Her recent publications include with Hossein Vahid Dastjerdi, Yasamin Khosravani, Masoud Shokrollahi "Translation Quality Assessment (TQA): A Semiotic Model for Poetry Translation" in Lebende Sprachen journal (2011) and with Kazem Lotfipour Saedi, Translation Method. Isfahan: Payam daneshgahi, 2010 
Darjuish Nejadansari teaches English at the University of Isfahan. His research interest is pragmatics, EFL learning and discourse analysis. He recently published with Azizollah Dabaghi Varnosfadrani, The Effectiveness of Error Correction on the Learning of Morphological and Syntactic Features. World Journal of English Language, 2010 and with BehroozGhoorchaei, Mansoor Tavakoi, The Impact Of Portfolio Assessment On Iranian EFL Students' Essay Writing: A Process-Oriented Approach. GEMA online Journal of Language Studies, 2010. 